\title{
Toll Like receptor 7 regulates viral loads and cytokine secretion during acute retroviral infection
}

\author{
E Browne \\ From AIDS Vaccine 2012 \\ Boston, MA, USA. 9-12 September 2012
}

\begin{abstract}
Background
Acute HIV infection is characterized by a high viremia accompanied by a powerful wave of pro-inflammatory cytokines that affects the subsequent course of infection and pathogenesis. Thus, understanding the mechanisms that regulate cytokine secretion and viremia is a key priority. The innate immune receptor TLR7 has been identified a retrovirus-sensing protein, and is expressed in several key immune lineages. In vitro data suggests that HIV can trigger TLR7-dependent innate immune responses, but TLR7s role in vivo is unclear.
\end{abstract}

\section{Methods}

To determine whether TLR7 affects viremia or cytokine secretion during acute retroviral infection, we analyzed the plasma of wild type and TLR7 deficient mice infected with the model retrovirus, Friend virus (FV).

\section{Results}

We identified 16 cytokines that are significantly upregulated in the plasma of wild-type mice infected with FV, the majority of which are also upregulated during HIV infection. Individual cytokines have distinct kinetic profiles and intensities, with peak levels ranging from $5 \mathrm{dpi}$ to $14 \mathrm{dpi}$. To examine the contribution of TLR7 to this response, we compared viral loads and cytokine levels of wild-type or TLR7 deficient mice. Surprisingly, we found that majority of the pro-inflammatory cytokines exhibited exacerbated secretion in the absence of TLR7, while only an early wave of the anti-inflammatory cytokine IL-10 was attenuated. This exacerbated cytokine storm was accompanied by an elevated viremia. Significantly, IL-10 deficient mice also exhibited elevated viremia and cytokine secretion during acute infection. By contrast, TLR7deficient mice exhibit an

Massachusetts Institute of Technology, Cambridge, MA, USA attenuated antibody response, while anti-viral antibody levels in IL-10 deficient mice were normal.

\section{Conclusion}

Our results demonstrate that TLR7 negatively regulates viral loads and cytokine secretion during acute retroviral infection by promoting an early wave of IL-10, and that TLR7 regulates the development of anti-viral antibodies independently of IL-10. These results reveal that TLR7 plays multiple roles in regulating the immune response to retroviral infection.

Published: 13 September 2012

doi:10.1186/1742-4690-9-S2-P174

Cite this article as: Browne: Toll Like receptor 7 regulates viral loads and cytokine secretion during acute retroviral infection. Retrovirology 20129 (Suppl 2):P174.

Submit your next manuscript to BioMed Central and take full advantage of:

- Convenient online submission

- Thorough peer review

- No space constraints or color figure charges

- Immediate publication on acceptance

- Inclusion in PubMed, CAS, Scopus and Google Scholar

- Research which is freely available for redistribution
( 2012 Browne; licensee BioMed Central Ltd. This is an Open Access article distributed under the terms of the Creative Commons Attribution License (http://creativecommons.org/licenses/by/2.0), which permits unrestricted use, distribution, and reproduction in any medium, provided the original work is properly cited. 